\title{
Higher education strategies for the 21st century: philosophical foundations and the humanist approach
}

\section{Estratégias de educação superior para o século 21: fundamentos filosóficos e a abordagem humanista}

\section{Estrategias de educación superior para el siglo XXI: fundamentos filosóficos y enfoque humanista}

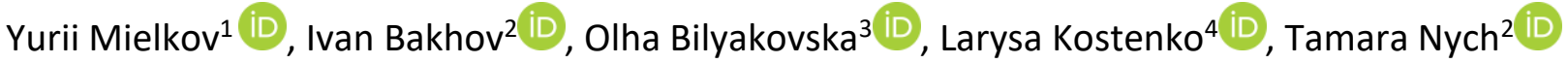 \\ ${ }^{1}$ Institute of Institute of Higher Education of the National Academy of Educational Sciences of Ukraine, Kiyv, Ukraine. \\ ${ }^{2}$ Interregional Academy of Personnel Management, Kyiv, Ukraine. \\ ${ }^{3}$ Ivan Franko National University of Lviv, Lviv, Ukraine. \\ ${ }^{4}$ Education Department of Kropyvnytskyi Town's Council, Kropyvnytsky, Ukraine.
}

Corresponding author:

Yurii Mielkov

Email: nauk_org_undip@ukr.net

How to cite: Mielkov, Y., Bakhov, I., Bilyakovska, O., Kostenko, L., \& Nych, T. (2021). Higher education strategies for the 21st century: philosophical foundations and the humanist approach. Revista Tempos e Espaços em Educação, 14(33), e15524. http://dx.doi.org/10.20952/revtee.v14i33.15524

\begin{abstract}
The paper is dedicated to a philosophical consideration of the transformation strategies for higher education, particularly those revealed by the current Covid-19 pandemic. The situation of the latter is presented as a particular form of the general VUCA characteristics of the today's world of uncertainty, unpredictability and qualitative complexity ('supercomplexity'). It is argued that the main result of our acknowledgement of the VUCA situation in the world for higher education is the image of the developed human personality becoming the main value and at the same time the main goal of higher education. Under the conditions of volatility and ambiguity, any existing 'ready-made' knowledge, as well as any instructions for effective rational behavior, turns to be inadequate. Because of that, it is no longer sufficient to have a set of 'competences' as a final result of the educational process at today's university. Higher education has to turn to developing in its graduates certain multidisciplinary qualities, like critical independent thinking and ability to create one's own knowledge, up to aiming at an all-round development of cultured personality. The paper argues that the education of critical and creative thinking is closely related to the transition to student-centered learning, as each individual student is to become a full-powered subject of the educational process according to one's own interests, abilities and curricula, with the role of a teacher starting to resemble that of a moderator, the one who is to help his or her undergraduates to navigate through the vast ocean of available information in order for them to choose and to create their own,
\end{abstract}


personal knowledge. The latter task is especially enforced by the distant and online learning having become popular during the Covid-19 pandemic: that form of learning puts especially high demands on self-discipline and self-responsibility of a student's personality, while presenting itself as rather a supplement than a replacement to more traditional forms of higher education with personal communication between student and teacher.

Keywords: COVID-19. Higher education. Humanist approach in education. Philosophy of education. Student-focused education. Super-complexity.

\section{RESUMO}

O artigo é dedicado a uma consideração filosófica das estratégias de transformação para o ensino superior, particularmente aquelas reveladas pela atual pandemia de Covid-19. A situação deste último é apresentada como uma forma particular das características gerais do VUCA do mundo de hoje de incerteza, imprevisibilidade e complexidade qualitativa ('supercomplexidade'). Argumentase que o principal resultado do nosso reconhecimento da situação da VUCA no mundo para o ensino superior é a imagem da personalidade humana desenvolvida tornando-se o valor principal e ao mesmo tempo o objetivo principal do ensino superior. Sob as condições de volatilidade e ambigüidade, qualquer conhecimento "pronto" existente, bem como quaisquer instruções para um comportamento racional eficaz, tornam-se inadequados. Por isso, já não é suficiente ter um conjunto de 'competências' como resultado final do processo educacional na universidade de hoje. $O$ ensino superior tem que se voltar para desenvolver em seus graduados certas qualidades multidisciplinares, como pensamento crítico independente e capacidade de criar o próprio conhecimento, até almejar um desenvolvimento integral da personalidade culta. $\mathrm{O}$ artigo argumenta que a educação do pensamento crítico e criativo está intimamente relacionada à transição para a aprendizagem centrada no aluno, uma vez que cada aluno deve se tornar um sujeito poderoso do processo educacional de acordo com seus próprios interesses, habilidades e currículos, com o papel de um professor que começa a se assemelhar ao de um moderador, aquele que deve ajudar seus alunos a navegar no vasto oceano de informações disponíveis para que eles escolham e criem seus próprios conhecimentos pessoais. A última tarefa é especialmente reforçada pela aprendizagem à distância e online que se tornou popular durante a pandemia de Covid-19: essa forma de aprendizagem coloca demandas especialmente altas de autodisciplina e responsabilidade da personalidade de um aluno, ao mesmo tempo que se apresenta como um suplemento do que uma substituição para formas mais tradicionais de ensino superior com comunicação pessoal entre aluno e professor.

Palavras-chave: Abordagem humanista na educação. COVID-19. Educação focada no aluno. Ensino superior. Filosofia da educação. Supercomplexidade.

\section{RESUMEN}

El documento está dedicado a una consideración filosófica de las estrategias de transformación para la educación superior, particularmente las reveladas por la pandemia actual de Covid-19. La situación de este último se presenta como una forma particular de las características generales de VUCA del mundo actual de incertidumbre, imprevisibilidad y complejidad cualitativa ("supercomplejidad"). Se argumenta que el principal resultado de nuestro reconocimiento de la situación VUCA en el mundo para la educación superior es la imagen de la personalidad humana desarrollada convirtiéndose en el principal valor y al mismo tiempo en el principal objetivo de la educación superior. En las condiciones de volatilidad y ambigüedad, cualquier conocimiento "prefabricado" existente, así como cualquier instrucción para un comportamiento racional eficaz, resultan inadecuados. Por eso, ya no es suficiente tener un conjunto de "competencias" como resultado final del proceso educativo en la universidad actual. La educación superior debe apuntar a desarrollar en sus graduados ciertas cualidades multidisciplinarias, como el pensamiento crítico 
independiente y la capacidad de crear el propio conocimiento, hasta apuntar al desarrollo integral de una personalidad culta. El documento sostiene que la educación del pensamiento crítico y creativo está estrechamente relacionada con la transición al aprendizaje centrado en el estudiante, ya que cada estudiante individual debe convertirse en un sujeto pleno del proceso educativo de acuerdo con los propios intereses, habilidades y planes de estudio, con el papel de un maestro que comienza a parecerse al de un moderador, el que debe ayudar a sus estudiantes a navegar a través del vasto océano de información disponible para que ellos elijan y creen su propio conocimiento personal. Esta última tarea se ve reforzada especialmente por el aprendizaje a distancia y en línea que se ha hecho popular durante la pandemia de Covid-19: esa forma de aprendizaje impone exigencias especialmente altas a la autodisciplina y la responsabilidad propia de la personalidad de un estudiante, al tiempo que se presenta como un complemento que un reemplazo a formas más tradicionales de educación superior con comunicación personal entre alumno y profesor.

Palabras clave: COVID-19. Educación centrada en el estudiante. Educación más alta. Enfoque humanista en educación. Filosofía de la educación. Supercomplejidad.

\section{INTRODUCTION}

In 2020, the world has changed rather rapidly and unexpectedly. The Covid-19 pandemic has influenced both the everyday and the professional activity of millions of people of many nations, forcing them to change the familiar lifestyle and the working methods they were accustomed to. Since the very beginning of the pandemic, some sociologists and political scientists have argued that after the quarantine, the world will never be the same again, and this prediction is gradually coming true before our eyes. Higher education is not an exception, and the post-Covid higher education is quite a popular research topic nowadays, with academics considering the ways and possibilities of online learning, economic consequences for small and private HEls, predictions on the enrollment etc. (Dennis, 2020; Marinoni et al., 2020).

Still, we would argue that the consideration of more fundamental philosophical aspects of the current transformations in higher education is no less necessary and urgent, as in our opinion the pandemic situation serves as a form of catalyst manifesting and strengthening the tendencies already present in higher education in today's world. It is not that Covid-19 has brought into the agenda for the $21^{\text {st }} \mathrm{c}$. any radically new issues - it has rather revealed the already present problems and immanent shortcomings of the existing education system. And those problems could not be reduced to just the formal and/or superficial questions like that of managing the online education and making its different forms available to the broader audience, as the strategies in question require the consideration of more profound problems that relate to providing the students with the very ability to master any new forms of education and activity in general in the situation of the complex and changing world.

Already in the 2018, in the report of the Club of Rome titled "Come On! Capitalism, Shorttermism, Population and the Destruction of the Planet", Ernst von Weizsäcker and Anders Wijkman (2018, p. 196), the chairmen of this respectable international organization, has argued that the needs of the contemporary situation "require a fundamental shift - from learning how to memorize and understand - to learning how to think in new, systemic ways. The real challenge is to develop in all students a capacity for problem solving, as well as critical, independent and original thinking". The Covid-19 pandemic has proven that the task in question is not just a wishful thinking on the part of philosophers or some reminiscence of the classical ideal of higher education as a process of developing a wholeness of human personality, but a challenge of the present-day situation as well.

The aim of this paper would be to outline the major philosophical and Weltanschauung foundations for the transformation of higher education strategies in order for them to fit the features of the world of the $21^{\text {st }}$ century, with the main focus being centered on the humanist approach in higher education. 


\section{METHODOLOGY}

The methodological basis of the current investigation is composed out of a number of empirical and theoretical methods. Particularly, the analytic method is used for studying the available sources and the data of surveys; comparative method is used for consideration of different strategies and scenarios of future development of higher education and human civilization in general. The most important for us its still the post-non-classical methodology proposed by Vyacheslav Stepin (2005), as a replacement for classical unity and non-classical radical plurality while dialectically combining unity in plurality and developing non-linear thinking: according to Stepin, currently the new type of scientific rationality features introduction of human cultural values into the very core of knowledge as our cognition turns its attention toward complex objects that are found to be "human-commensurable"; such methodology serves as the methodological basis for the consideration of human-centered approach in higher education.

\section{FINDINGS}

The philosophical consideration of the problem in question and the review of the already available sources would be better started with the analyses of the features of the current world situation and the challenges it presents for higher education. We could refer here to the acronym VUCA ('Volatility, Uncertainty, Complexity, Ambiguity'), its basic idea first having been introduced in 1985 (Bennis \& Nanus, 1985, p. 226), in order to denote those very features. Later this concept became widespread in the US military circles and used to describe the situation in the world after the end of the Cold War and the collapse of the Soviet Union - it is easy to see that such an approach opposed the overly optimistic interpretation of the same situation by neoliberal scholars like Francis Fukuyama (1989), who interpreted it as 'the end of history'. In difference from the latter views on the now monopolar world where the Western liberal democracy had been overpowered any ideological opposition and has been finally universalized, the VUCA concept characterized world as complex and multipolar in principle - particularly, in the context of military education supposed to prepare US Army officers for life and professional activity in unusual circumstances of the $21^{\text {st }}$ century. In 1996, in a kind of 'textbook' or reference book for military managers by Robert Murphy (1996, pp. 440-441) of the U.S. Army War College made the first conscious use of this abbreviation: "In situations that are characterized by volatile, uncertain, complex, and ambiguous (VUCA) conditions, it becomes necessary to structure organizations in such a way that will meet the challenges presented by the environment".

At that time, it was still difficult for researchers to offer a clear explanation of these characteristics - and even more so to formulate the necessary measures for dealing with those appropriate conditions ("meeting the challenges presented by the environment" sounds in this context rather vague and indefinite). It is also worth noting that all the classic features of the VUCA situation are actually negative, manifesting just some contrast in relation to the former features and conditions - certain simplicity, stability and predictability of the previous world-picture. Moreover, volatility, uncertainty and ambiguity - that is, three of the four characteristics included in the abbreviation - can be represented as a kind of similar, if not identical, phenomena. The ability of the today's world to change quickly in the eyes of one generation of people turns into a certain feeling of insecurity towards the future, awareness of the unpredictability of such changes, incomprehension of their consequences, the inability to compare them with the causes and unambiguously predict the results of one's own actions.

On the other hand, complexity is almost the only (of the four mentioned), so to speak, 'positive' features of the today's world's conditions and the course of events in that world - it is quite obvious that such a complexity could not be reduced to a purely military or political characteristics of the situation, but fully applies to other spheres of life as well. Although loosely 
associated with the same feeling of confusion before unexpected phenomena, it is still a more interesting subject for philosophical consideration, which is directly related to education in particular and to the field of human knowledge in general. We mean complexity as a certain abundance of human knowledge on the surrounding world: according to some recent estimates, expressed by bibliometric analysts in Germany and Switzerland, the mass of scientific output growth with the rate of $8-9 \%$ each year, which corresponds to a doubling of global scientific knowledge roughly every nine years (Van Noorden, 2014), (although other known estimates range from five to fifteen years). And this very fact has a lot of influence on the practices of higher education, as in order to be well-versed in their own professional field, professors and university staff members must constantly monitor at least the major latest publications and theories. How is that possible even within a relatively narrow field of research is another question: on the one hand, a professor - particularly here in Ukraine - is burdened with class teaching hours and does not have so much time for research and scientific information activities, to say nothing of the restricted access to many publication that require payments unsuitable even for many HEls in the developing countries; on the other hand, due to the now common knowledge of English as the dominant language of international scientific communication and the access to open international information networks, such monitoring today is still somewhat simplified.

However, the problem in question is not only and not so much about teachers providing with students' relevant knowledge, - that is, not only about the situation of, so to say, 'simple' complexity caused just and above all by a significant amount - abundance - of such information. The fact is that in a world of instability, uncertainty and unpredictability, any existing knowledge is irrelevant in that or another way - it either becomes obsolete relatively quickly after its 'providing', or even is already obsolete at the time of its transfer from teacher to student. As an example, computer skills have changed entirely just in the two last decades due to the rapid spread of information technologies and the popularization of first personal computers, then that of online technologies, and finally - in the eyes of modern youth - of mobile devices. Just two or three decades ago, students used to study almost in the same way their parents and the parents of their parents did a decade or a century ago, facing some difficulties while accessing new sources, especially those of foreign origin, but being quite good at using traditional libraries and even successfully distinguishing primary and reliable sources from secondary and dubious ones, - while the present generation faces completely different, sometimes even opposite problems.

Such a situation, somewhat different from the 'simple' complexity caused by the abundance of information and long witnessed in the VUCA abbreviation, has been named by researchers as 'complexitiness', following the term proposed by Russian experts in the theory of self-organization, who understand it as a fork of fundamental, essential complexity and irreducibility to simple phenomena and factors (Svirskiy, 2011), and 'supercomplexity'. The latter concept belongs to British philosopher of education Ronald Barnett, who explains that complexity - i.e. 'simple', the usual complexity - arises as a result of excessive data, ideas or resources within a discrete situation (when, for example, a doctor is burdened with information about new drugs or about new methods of medical intervention, or when he or she has to make a reception of many patients in a limited period of time, etc.), while the situation of 'supercomplexity' characterizes the challenges that surpass the limits of such a situation. Under such conditions, the same doctor is forced, for example, to act at the same time as a manager of valuable resources on behalf of the state, to rethink his or her relationship with patients basing on new market principles or to reassess one's traditional attitude to 'alternative medicine' -in other words, the doctor in question faces the need to change the Weltanschauung foundations of his or her activities in a fundamental way. The university, argues Barnett (2000, pp. 115-116), is related to such supercomplexity, first, as a factor that is partly to blame for its emergence (as an institution that has been engaged in and is producing new paradigms of comprehension of reality); secondly, as an agency responsible for the preparation of the younger 
generation for life in a world of complexity by promoting the development of relevant qualities in its representatives; and thirdly - in terms of public and educational mission of the university in understanding and affirming the complexity as a global phenomenon.

\section{DISCUSSION}

Thus, it is not surprising that the VUCA conception and the general comprehending of the today's world situation in terms of qualitative supercomplexity provides great challenges for higher education - and especially for its philosophical foundation, its understanding its own mission under such complex and ambiguous conditions. It is all about educating a person able to live in a world of complexity, nonlinearity, uncertainty. That is, the world where any 'ready-made' knowledge, as already mentioned, turns to be inadequate, and any 'instructions' for effective rational behavior either everyday and personal or strictly professional - are absent (because it is virtually impossible to predict the course of events in a complex nonlinear world), or they are at least fundamentally incomplete and subject to become outdated very quickly.

How to deal with the VUCA conditions? Bill George from the Harvard Business School has presented recently a contemporary attempt to clarify the question of 'answering the challenges of the VUCA world'. According to him, the situation of 'VUCA 2.0', which occurred in 2010s, is to be handled by a manager with such qualities as 'Vision, Understanding, Courage, and Adaptability' (George, 2017). The first component means the ability to clearly see in the chaos of circumstances the mission, values and strategies of one's organization; 'Understanding' indicates knowledge of one's capabilities and tendency to acknowledge alternative points of view; 'Courage' symbolizes making risky decisions in response to challenges while stepping away from 'safe', familiar and traditional management methods; finally, the 'adaptability' requires unprecedented flexibility in relation to the environment and rapidly changing circumstances. However, we should note that such proposed strategies are rather purely business-related and, in many respects, resemble echoes of the old 'economic centrism' of the Modernity age - especially since, say, 'adaptability' clearly hints at the maladaptation of any long-term plans and, ultimately, stable values or ideals. In addition, it is not entirely clear how 'vision' could be nurtured under the conditions of unpredictability, and what is even more important - it is hard for us to agree that the qualities that would cope with the challenges of complexity and ambiguity of the world should be cherished in managers only. Rather, it makes sense to say that the purpose of higher education is the formation of the qualities needed to deal with the VUCA world in representatives of all specialties, because the implementation of the desired scenario of the future better (and just existing) world depends literally on the actions of each single person, and not only those of top managers or politicians.

We would argue that the main result of our acknowledgement of the VUCA situation in the world for higher education is the image of the developed human personality posed as the main value and at the same time the main goal of higher education, because that's who is able to live and act in the world characterized by unpredictability and complexity - and especially by different risks that should be assessed by the degree of desirability of all their possible consequences. In other words, it is no longer sufficient to have a set of 'competences' as a final result of the educational process at today's university, that is, to have some specific knowledge and skills that the graduate must acquire in accordance with the ideas of the $20^{\text {th }}$ century - we now have to aim at a holistic personality endowed with certain human qualities, certain modes of existence that would allow a person to deal with the challenges of the new circumstances. The described situation of supercomplexity and uncertainty turns into realizing that, as we have already mentioned, today we lack any ready-made knowledge guaranteed to work. A contemporary student can be taught not so some efficient skills or given any true knowledge, but first of all an ability to create, to generate one's own knowledge. 
In fact, that idea corresponds both to the notion of forming critical and independent thinking as the new strategy and frontier for higher education of the $21^{\text {st }} \mathrm{c}$. - and to the concepts of classical thought in the field of philosophy of education. In particular, it is worth mentioning the ideas of José Ortega y Gasset, who defined the mission of the European University as teaching a student to be a cultured person, as opposed to teaching just specific professional competencies. The latter, taken in their isolated form, present but an alienated fullness of human qualities, the 'one-dimensionality' (in famous term by Herbert Marcuse) of the human personality, thus demonstrating a kind of fragmentation and disintegration of human personality as a whole. According to the Spanish philosopher, this could be defined as the main problem of the higher education system of the $20^{\text {th }}$ century:

El carácter catastrófico de la situación presente europea se debe a que el inglés medio, el francés medio, el alemán medio son incultos, no poseen el sistema vital de ideas sobre el mundo y el hombre correspondientes al tiempo. Ese personaje medio es el nuevo bárbaro, retrasado con respecto a su época, arcaico y primitivo en comparación con la terrible actualidad y fecha de sus problemas. Este nuevo bárbaro es principalmente el profesional, más sabio que nunca, pero más inculto tambiénel ingeniero, el médico, el abogado, el científico (Ortega y Gasset, 1966, p. 222).

A sad, but illustrative example, of how the lack of general culture in a situation of 'supercomplexity could lead a contemporary specialist (as kind of Ortega's 'new barbarian') to illdoomed decisions, is the 1986 accident at the Chernobyl nuclear power plant in Ukraine (which reflects the general situation with many types of modern complex equipment operating in industry). Today, more than three decades later, neither the unambiguous causes nor the individual culprits of the accident could be identified: as it was aptly stated in the 1986 report by the International Atomic Energy Agency, the core cause of the catastrophe was an unlikely coincidence, and to talk about an error or illegitimacy of the actions of personnel in such an unpredictable situation is impossible given the contradictory requirements of the regulations for the operation of a reactor of this type. Probably the clearest general picture of the factors that had led to the accident was outlined by Valery Legasov (1988), the former chief of the Soviet commission on investigation of the 1986 Chernobyl disaster.

According to him, it was the 'bad philosophy of safety' that led to the catastrophe: the reactors of RBMK type (used in Chernobyl) were historically the first to be put into operation in the field of nuclear energy in the USSR, when safety requirements and instructions were still almost absent. However, given the military origins of nuclear technology in general, the personnel of the first nuclear power plants, consisting almost exclusively of servicemen accustomed to working in situations of constant risk and unpredictability, was extremely highly qualified, careful and disciplined (let us also remind about the military origins of the VUCA conception as well). Over the years, the tacit requirements for strict reactor maintenance procedures have eased, and new generations of engineers, for all their professional competence, have been uncritical of the equipment they were to operate and of the safety conditions in its operation. That is, it is not competence in a particular specific area of activity that was necessary in order to prevent undesirable accidents, and certainly not the ability to follow instructions (as for RBMK type reactors they were rather vague, if not contradictory, and could not deal with unpredictable situations), but rather the general culture of an individual, including the culture of safety and the ability to assess all the possible risks regardless of any customs and rules.

Today, in the $21^{\text {st }}$ century turmoil, due to the constant improvement and the growing complexity of technologies, such situations may well become more and more frequent, and not just in nuclear plants, but in other fields as well. Therefore, we are in need of human persons able to assess all the risks in a much broader perspective than any single area of expertise - persons capable of thinking creatively and independently, 'out of the boxes' of any pre-existing frameworks. 
According to the results of a survey of employers conducted several years ago by the Association of American Colleges and Universities, of the most importance for contemporary employers are the interdisciplinary qualities of a graduate, which are not limited to a purely professional, narrow range of knowledge and skills: written and oral communication, teamwork skills, ethical decision-making, critical thinking, and the ability to apply knowledge in real-world settings. $91 \%$ of the surveyed employers expressed the belief that "a demonstrated capacity to think critically, communicate clearly, and solve complex problems is more important than [a candidate's] undergraduate major" (Association of American Colleges \& Universities, 2015).

Of course, such statements and examples don't mean that we stand for abandoning the professional component of higher education in favor of educating 'universal creative personalities' without any specific major - it would be but a meaningless utopia. After all, an ability to think out of the box under qualitatively complex situations, and creative and critical thinking in general, should rather complement and improve than replace all other professional skills and abilities. Accordingly, the methodological task is to find the right balance between the breadth and the depth of educational programs in contemporary HEls - and to help undergraduates to acquire the necessary basic skills in their major while providing them with knowledge on other fields of science, art, philosophy etc. and to help them to develop a broader Weltanschauung, a significant level of general culture - that is, to get everything they need for further independent development of their own personality.

It would be also interesting to note that the said 'complexity' of the world relates not so and not only to the objective reality itself, as to the observers comprehending and evaluating that reality: its qualitative complexity reflects the complexity of their own personalities. It is human person that becomes complex under the paradigm of multiculturalism (Bakhov, 2013; Holovatyi, 2014; Mielkov, 2017), and the plurality of human cultural identities, as well as their ongoing proliferation, has its impact both on our understanding of the external world and on the strategies of civilization development, especially including those of higher education.

Such an approach in fact refers to the humanistic core of higher education and its philosophical foundations: in order for the higher education to shape and to develop human personality, it has to be fully aware of the self-worth of the student's very personality, to ensure his or her status as a full subject of the educational process - to respect the student's autonomy, as argued by one of the leading educational thinkers of the $20^{\text {th }}$ c. Paolo Freire $(2001$, p. 59$)$ who was talking about the need to reform the 'teacher - student' relationship from asymmetric to symmetrical, bidirectional, 'teacher - student' and 'student - teacher'. If we turn to more practical issues, the education of critical and creative thinking is inseparable from such a strategic transformation of today's higher education as the transition to the so-called student-focused, student-centered learning, up to the classical ideas of comprehensive personal development. A good example of that is the proposal to reform Hong Kong's education for the $21^{\text {st }}$ century published in September 2000 by the Education Commission, the region's leading administrative body for education. The strategic emphasis was put there on the transition to 'student-focused education', that "should aim to develop students' interest in learning, communication skills, creativity as well as sense of commitment so as to prepare them for life-long learning. It should enable every student to achieve an all-round development according to his/her own attributes" (Hong Kong Special Administrative Region of the People's Republic of China, 2000, p. 57). The plan also emphasizes on the need for the need for moral, emotional, spiritual education, in particular, in order to help students to develop a "healthy outlook to life".

In Ukraine, this idea is just beginning to be understood and implemented; in particular, in December 2019, the amendments were made to the 2014 Law of Ukraine "On Higher Education", which supplemented it with appropriate definitions of terms and concepts: 
Student-centered learning - an approach to the organization of the educational process, which involves: encouraging higher education students to play the role of autonomous and responsible subjects of the educational process; creation of an educational environment focused on meeting the needs and interests of applicants for higher education, in particular providing opportunities for the formation of an individual educational trajectory; building the educational process on the basis of mutual respect and partnership between the participants of the educational process (The Law of Ukraine, 2014).

It is worth mentioning that the transition to 'student-focused education' does not mean that higher education used to be 'teacher-oriented' instead of 'student-oriented', and has to be in a way re-directed: rather, it means that the focus on the personality of not only the student but the teacher as well should come to the fore - in opposition to the linear-modern orientation on the formality of education, on some standard, stable and unchanging, as they are called in the text of the Law, 'educational trajectories'. That is, it is the issue of de-formalizing the educational process and re-orienting it on cultivation of the creativity in both the student and the teacher. That issue also means radical democratization: each individual student should become a subject of the educational process according to one's own trajectory and curriculum - alongside with a teacher who will be able to help student adapt that curriculum to his or her abilities and interests. That is, it is kind of a personal, humanistic approach in the practice of higher education.

We would argue that such humanist and personalist approach in higher education is the ground for the formation of culture, critical thinking, and the ability to deal with any surprises of the unstable and complex world. One of the founders of the philosophical current of personalism, Emmanuel Mounier (1961, p. 45), has generally defined personality as something 'indefinable' in each human that can't be considered as an object, "Elle est même ce qui dans chaque homme ne peut être traité comme un objet". Similarly, humanism refers to the ability of each unique human personality to act as a subject of one's own life and activities (and not an object of any plans, programs and curricula), as well as to the fact that it is the human nature as a whole that takes part in learning, creativity, activity - and not just the mind, not only the rational side of personality. Human emotions and human will, the appeal to the value and the morality are also relevant and necessary for the tasks of higher education. As defined by South Korean researcher K. Yoon, the principles of the contemporary education reforms lies in shifting educational emphasis from: a) subject knowledge to nurturing moral character; b) standardization to autonomy, diversification, and specialization; c) provider to consumer; d) closed education occurring within the boundary of classrooms to open and lifelong education; e) cademic sectarianism to individual capability; and f) quantitative growth to qualitative improvement (Mok, 2006, p. 177).

As a proof for the growing (and decisive) role of each student as a subject of educational process and the irreversible de-standardization and de-formalization of the latter, we could refer to the very topic that we have started with: namely, the Covid-19 pandemic that forced contemporary universities all over the world to adopt forms of online education in a short period of time. According to the survey by the International Association of Universities, already in May 2020 two-thirds of the HEls reported that classroom teaching has been replaced by distance teaching and learning (Marinoni et al., 2020, p. 23). In spite of the transition being quite sudden so that many students, teachers and institutions were unprepared for the shift, especially in poorer and developing countries, it has and will have great impact on the future of higher education (regardless of how and when will the pandemic end). As stated by the authors of the quoted report and survey evaluation:

This unplanned and unprepared experiment in distance teaching and learning has led to capacity building of staff and faculty who have learned and tested new tools and systems to enable distance teaching and learning. It is therefore possible that a shift in mindset is happening or that this experience has opened a new horizon of opportunities for teaching and learning. 
Respondents believe that this will offer a push forward in terms of exploring the potential of flexible learning and more acceptance for online learning to become a more integral part of study plans (Marinoni et al., 2020, p. 26).

In any case, distance teaching and learning has now become a reality of the educational process in most universities in the world. And not only because of the Covid-19: as we have already noted earlier, due to the rapid spread of information technologies and the Internet access, on the one hand, students now have the access to a virtually limitless information repository of the knowledge of human civilization. On the other hand, that leads to a radical change in the role of the university teacher. From the paradigm and methods of 'informing', as in the form of classical 'teacher to student' interaction, where the former used to transfer knowledge and skills to the latter, we now move not so to the subject-subject communication (where the two democratically equal subjects exchange knowledge and opinions), but to a kind of moderation. From a mentor who possesses unique knowledge and is able to pass it on to the next generation, the university professor becomes a supervisor who is to help his or her undergraduates to navigate through the boundless ocean of available and accessible information in order for them to choose and create their own, personal knowledge out of the available information.

And that's what stresses the importance of the personal development and responsibility of both student and teacher, as they become virtually sole authority as to their following all the curricula and all the deadlines, with no external power to lead or to control them. While the history of distance learning dates back to the $19^{\text {th }}$ century, the most interesting types of online courses started to appear about 2010, namely the asynchronous courses that provide an ability to study the materials of a chosen discipline at any pace, without having to follow any standard mode of operation of an educational institution, even remotely. Such asynchronous courses, which are often abbreviated as MOOC ('Massive open online courses'), are really accessible to everyone, as theoretically they have no limits on the number of participants in the educational process and have almost to no term deadlines for studying the material. Most importantly, they allow people to gather high-quality knowledge anytime, anywhere on the Internet: a consumer of their services can easily access educational content provided by leading universities in the United States and other countries, like Harvard University, MIT, Stanford University et al. Thanks to online education platforms such as Coursera, Udacity, edEX, FutureLearn, etc., the space of higher education no longer has any national borders, and its internationalization acquires a new dimension, easier to implement comparing to the usual academic mobility that requires physical (and quite expensive) travel to other countries.

Of course, MOOC has a lot of its own drawbacks and problems related to the not lack of personal communication between the classmates or between teachers and students; because of that, sometimes they introduce some forms of course deadlines in order to ensure the formation of a community and to motivate part-time students, who are not forced to successfully complete their studies by anything except for their own self-discipline. Low success rates were still characteristic of non-electronic forms of distance learning, and the online situation did not improve that at all, supplemented by a large number of 'self-withdrawals': according to the 2010s statistics, if at the high school level an average of $27 \%$ of participants graduates, university students do not exceed $8 \%$ of that rate, and among graduate students such index is close to 5\% (Kizilcec et al., 2013, p. 3). Among the reasons for the withdrawals of MOOC students, the surveys mention both the high complexity and, conversely, the excessive simplicity of a course: not all teachers manage to maintain a balance of theory and practice, to say nothing of any kind of 'personal approach' to the needs and skills of the hundreds and thousands of students.

All that but suggests that 'mass online courses' are in no way an alternative or a competitor to the educational process in the traditional HEls, but a kind of complementary practice that could well contributes to the internationalization of education and to the students' personal 
development, while simplifying some elements of their curricula. The same approach is advocated by Salman Khan, an American entrepreneur with Bengali roots and the founder of one of the most popular MOOC platforms, Khan Academy: the purpose of the latter is to create a set of online tools that would not replace, but complement the traditional university education - without any claims to completeness, but as an auxiliary material to consolidate the knowledge gained in a more familiar way. Practical lessons and knowledge testing, not to mention creative tasks, could be better performed only in direct personal communication between the student and the teacher, and mass online courses can't provide that in principle. And this is both their main drawback and a clear indication that only a mixed mode and a combined educational trajectory, not just distance learning, is related to the higher education strategies for the $21^{\text {st }} \mathrm{c}$. aimed at providing a realization of the "student-centered learning" and the humanistic approach, by developing human personalities capable of living and acting in the world of uncertainly and complexity.

\section{CONCLUSION}

The conducted research allows to draw the following conclusions. The pandemic situation we have experienced since 2020 serves as a form of catalyst manifesting the tendencies present in today's world and forcing higher education to develop strategies suitable to the situation of the $21^{\text {st }}$ century. The latter is best characterized as VUCA: in the world of volatility, uncertainty, complexity and ambiguity, any existing 'ready-made' knowledge, as well as any instructions for effective rational behavior, turns to be inadequate. Because of that, it is no longer sufficient to have a set of 'competences' as a final result of the educational process at today's university, and higher education has to turn to developing multidisciplinary qualities, like critical independent thinking and ability to create, in its graduates, up to aiming at an all-round development of cultured personality.

On the practical side, the education of critical and creative thinking is inseparable from such a strategic transformation of today's higher education as the transition to student-focused, studentcentered learning. That strategic transformation does not mean replacing 'orientation on teacher' with that 'on student', rather, it means placing the focus on the personality of both student and teacher, as a kind of humanistic approach in higher education opposed to the linear-modern orientation on the formality of standards. That also means radical democratization: each individual student is to become a subject of the educational process according to one's own trajectory and curriculum, with the role of a teacher more resembling that of a moderator, the one who is to help his or her undergraduates to navigate through the body of available information in order for them to choose and create their own, personal knowledge. The latter task is especially enforced by the different forms of distant and online learning that became popular during the Covid-19 pandemic: on the one hand, they prove to be handy and useful means for accessible education at one's own pace that put especially high demands on self-discipline and self-responsibility, while on the other hand they are shown to serve as supplement and not a replacement to more traditional forms of higher education with personal communication between student and teacher or supervisor.

Most ideas expressed in this paper are of purely philosophical nature, and the issues of their further discussion, development, and practical implication could well serve as the subject of future research on the topic of higher education strategies for the $21^{\text {st }}$ century.

Authors' Contributions: Mielkov, Y.: conception and design, acquisition of data, analysis and interpretation of data, drafting the article, critical review of important intellectual content; Bakhov, I.: conception and design, acquisition of data, analysis and interpretation of data, drafting the article, critical review of important intellectual content; Bilyakovska, O.: conception and design, acquisition of data, analysis and interpretation of data, drafting the article, critical review of important intellectual content; Kostenko, L.: conception and design, acquisition of data, analysis and interpretation of data, drafting the article, critical review of important intellectual content; Nych, T.: conception and design, acquisition of data, analysis and interpretation of data, drafting the article, critical review of important intellectual content. All authors have read and approved the final version of the manuscript. 
Ethics Approval: Not applicable.

Acknowledgments: Not applicable.

\section{REFERENCES}

Association of American Colleges \& Universities. (2015). Employers Judge Recent Graduates III-Prepared for Today's Workplace, Endorse Broad and Project-Based Learning as Best Preparation for Career Opportunity and Long-Term Success. Washington, DC: The Association of American Colleges and Universities (AAC\&U). Available: https://www.aacu.org/press/press-releases/2015employerstudentsurveys

Bakhov, I. S. (2013). Government multicultural policy in Canada in the period of 1970-2000-s. Middle East Journal of Scientific Research, 15(10), 1450-1454.

Barnett, R. (2000). Reconfiguring the University. In: Scott, P. (Ed.). Higher Education Reformed. London and New York: Falmer Press, pp. 114-129.

Bennis, W., \& Nanus, B. (1985). Leaders: Strategies for Taking Charge. New York: Harper \& Raw.

Brito, R. S., Prado, J. R., \& Nunes, C. P. (2017). As condições de trabalho docente e o pós-estado de bem-estar social. Revista Tempos e Espaços em Educação, 10(23), 165-174. https://doi.org/10.20952/revtee.v10i23.6676

Dennis, M. (2020). Higher education opportunities after COVID-19. University World News. Available: https://www.universityworldnews.com/post.php?story=20200507152524762

Freire, P. (2001). Pedagogy of Freedom: Ethics, Democracy, and Civic Courage. Lanham, MD: Rowman \& Littlefield. Fukuyama, F. (1989). The End of History? The National Interest, 16, 3-18.

George, B. (2017). VUCA 2.0: A Strategy For Steady Leadership In An Unsteady World. Forbes. Available: https://www.forbes.com/sites/hbsworkingknowledge/2017/02/17/vuca-2-0-a-strategy-for-steady-leadership-in-anunsteady-world/

Holovatyi, M. F. (2014). Multiculturalism as a means of nations and countries interethnic unity achieving. Economic Annals-XXI, 11-12, 15-18.

Hong Kong Special Administrative Region of the People's Republic of China, Education Commission. (2000). Learning for life, learning through life: Reform proposals for the education system in Hong Kong. Education blueprint for the 21st century. Hong Kong: Education Commission. Available: https://www.ec.edu.hk/doc/en/publications and related documents/education reform/Edu-reform-eng.pdf

Kizilcec, R. F., Piech, C., \& Schneider, E. (2013). Deconstructing Disengagement: Analyzing Learner Subpopulations in Massive Open Online Courses. In: Suthers, D., Verbert, K., Duval. E. (Eds.). Proceedings of the Third International Conference on Learning Analytics and Knowledge. Stanford University. New York: Association for Computing Machinery, pp. 170-179. Available: https://web.stanford.edu/ cpiech/bio/papers/deconstructingDisengagement.pdf

The Law of Ukraine No. 1556-VII dated July 1, 2014 “On Higher Education”. The Verkhovna Rada of Ukraine. Available: https://zakon.rada.gov.ua/laws/show/1556-18/print (in Ukrainian).

Legasov, V. A. (1988). The Legasov Tapes. Available: https://legasovtapetranslation.blogspot.com

Marinoni, G., Land, H. van't, \& Jensen, T. (2020). The Impact of COVID-19 on Higher Education around the World. Paris: International Association of Universities. Available: https://www.iauaiu.net/IMG/pdf/iau covid19 and he survey report final may 2020.pdf

Mielkov, I. (2017). Human Personality in the Complex World: Pluralism of Identities and the Problem of WorldAttitude. Likarska Sprava, 7(1144), 168-174.

Mok, K. H. (2006). Education Reform and Education Policy in East Asia. London, New York: Routledge.

Mounier, E. (1961). Le personnalisme. In: Collection: Que sais-je? no 395, 7e édition. Paris: Les Presses universitaires de France. Available:

http://classiques.uqac.ca/classiques/Mounier Emmanuel/personnalisme/personnalisme intro.html

Murphy, R. M. (1996). Overview of Strategic Management. In Leading and Managing in the Strategic Arena: A Reference Text 1996-1997. Carlisle Barracks, PA: U.S. Army War College.

Ortega y Gasset, J. (1966). Misión de la Universidad. In: Obras Completas, Vol. IV. Madrid: Revista de Occidente, pp. 143-242. 
Stepin, V. S. (2005). Theoretical knowledge. Dordrecht: Springer Verlag.

Silva, L. R., Santos, A. R., \& Santos, I. T. R. (2020). Public policies for education of/in the field and the school environment in a settlement of the MST: the intimate relationship with the pedagogical policy. Journal of Research and Knowledge Spreading, 1(1), e11737. http://dx.doi.org/10.20952/jrks1111737

Svirskiy, Y. I. (2011). Innovation and 'complexitiness' thinking, In: Arshinov, V. I. (Ed.). Synergetic Paradigm: The Synergetics of Innovation Complexity. Moscow: Progress-Tradytsyia, pp. 300-312 (in Russian).

Van Noorden, R. (2014). Global scientific output doubles every nine years. Nature, News Blog. Available: http://blogs.nature.com/news/2014/05/global-scientific-output-doubles-every-nine-years.html

Weizsäcker, E. von, \& Wijkman, A. (2018). Come On! Capitalism, Short-termism, Population and the Destruction of the Planet - A Report to the Club of Rome. New York: Springer Verlag.

Received: 29 January 2021 | Accepted: 4 April 2021 | Published: 24 April 2021

This is an Open Access article distributed under the terms of the Creative Commons Attribution License, which permits unrestricted use, distribution, and reproduction in any medium, provided the original work is properly cited. 